Jurnal Akuntansi dan Bisnis: Jurnal Program studi Akuntansi, 5 (1) Mei 2019.

ISSN 2443-3071 (Print) ISSN 2503-0337 (Online). DOI: 10.31289/jab.v5i1.2454

JURNAL AKUNTANSI DAN BISNIS

Jurnal Program Studi Akuntansi

Available online http://ojs.uma.ac.id/index.php/jurnalakundanbisnis

\title{
PENGARUH PRAKTIK PERATAAN LABA PADA PERUSAHAAN TAMBANG YANG TERDAFTAR DI BURSA EFEK INDONESIA
}

\author{
Ayu Kurnia Sari ${ }^{a *}$, Hendra Saputra ${ }^{a}$, Wichita Ghekesia Nainggolan ${ }^{a}$ \\ a Universitas Pembangunan Panca Budi
}

Diterima April 2019; Disetujui April 2019; Dipublikasikan Mei 2019

\begin{abstract}
Abstrak
Penelitian ini bertujuan untuk mengetahui dan menganalisis apakah ukuran perusahaan dan profitabilitas berpengaruh signifikan secara parsial dan simultan terhadap praktik perataan laba. Jenis penelitian ini adalah data sekunder dengan pendekatan kuantitatif. Populasi dalam penelitian ini berjumlah 12 perusahaan pertambangan yang terdaftar di Bursa Efek Indonesia dari tahun 2012-2016. Metode pengambilan sampel adalah sensus, sehingga jumlah sampel yang digunakan adalah 60 data sampel. Metode analisis data menggunakan uji asumsi klasik, regresi linier berganda, uji determinasi, uji t (uji parsial), dan uji f (uji simultan). Hasil penelitian ini menunjukan bahwa ukuran perusahaan dan profitabilitas tidak berpengaruh secara parsial terhadap praktik perataan laba. Sedangkan secara simultan ukuran perusahaan dan profitabilitas berpengaruh signifikan terhadap praktik perataan laba (Studi kasus perusahaan pertambangan yang terdaftar di Bursa Efek Indonesia).
\end{abstract}

Kata Kunci : Ukuran Perusahaan, Profitabilitas dan Perataan Laba

\section{Abstract}

The aims of the research to know and analyze about whether the size of the company and profitability have a significant and partial or simultaneously effect on income smoothing practices. The typical data of research is secondary data with a quantitative approach. The population of this research were 12 mining companies which was listed in the Indonesia Stock Exchange from 2012-2016. The methodology of the the sample using census criteria, the total sample that was used 60 data. The analysis method used the classical assumption test, multiple linear regression, determination test, $t$ test (partial test), and f test (simultaneous test). The results of this research shows that company size and profitability did not partially affect the practice of income smoothing. Meanwhile when it saw from simultaneoussize of the company and profitability have a significant effect on income smoothing practices (Case study of mining companies listed on the Indonesia Stock Exchange).

Keyword: The size of the company, Profitability and Income smoothing

How To Cite: Sari, A. Y et, Al. (2019). Pengaruh Praktik Perataan Laba Pada Perusahaan Tambang Yang Terdaftar Di Bursa Efek Indonesia. Jurnal Akuntansi dan Bisnis: Jurnal Program Studi Akuntansi, 5 (1): 60-70

* email: ayukurniasari@ymail.com

\section{PENDAHULUAN}

Pada tahun 2007 saham pertambangan jadi favorit investor sehubungan dengan naiknya sejumlah komoditas tambang. Indeks saham pun langsung melejit termasuk Jakarta Islamic Index (JII) dan saham-saham yang naik harganya di top gainer antara lain, perusahaan sektor pertambangan yang tergabung di JII yaitu International Nickel Indonesia (INCO) naik Rp 2.400 menjadi Rp 44.900, Aneka Tambang (ANTM) naik Rp 400 
menjadi Rp 9.600. yang mana data ini dilansir oleh Bursa Efek Indonesia. Menguatnya harga minyak mentah dunia juga mempunyai pengaruh yang signifikan terhadap kinerja sektor pertambangan khususnya tambang batu bara dimana harga batu bara sebagai bahan bakar subtitusi ikut terangkat. Penguatan harga batu bara dunia dan meningkatnya volume penjualan kuartal pertama 2008 karena tingginya permintaan dalam dan luar negeri, telah memberikan pengaruh positif terhadap kinerja perusahaanperusahaan tambang batu bara, diantaranya perusahaan yang tergabung di JII seperti PT Tambang Batubara Bukit Asam Tbk (PTBA), PT Bumi Resource, Tbk. yang mencatatkan peningkatan laba (Bastian, H., et, al. 2018).

Menurut Zulhamri, L (2016), sulitnya memperoleh dana dari investor di Indonesia membuat perusahaan pertambangan mengalami kesulitan dalam mengembangkan bisnisnya dan memperoleh dana dari publik Indonesia sehingga membuat banyaknya perusahaan tersebut mencari dana dari luar negeri. Hal ini membuat Indonesia hanya menjadi tempat menjalankan aktivitas pertambangan. Dikatakan pengusaha pertambangan yang memiliki sedikit modal tidak akan mampu menanggung risiko yang ada dari usaha pertambangan sehingga membutuhkan dana dari publik untuk tetap menjalankan kegiatan usaha pertambangan termasuk Jakarta Islamic Index (JII) dan saham-saham yang naik harganya di top gainer antara lain, perusahaan sektor pertambangan yang tergabung di JII yaitu International Nickel Indonesia (INCO) naik Rp 2.400 menjadi Rp 44.900, Aneka Tambang (ANTM) naik Rp 400 menjadi Rp 9.600. (www.detikfinance.com). Menguatnya harga minyak mentah dunia juga mempunyai pengaruh yang signifikan terhadap kinerja sektor pertambangan khususnya tambang batu bara dimana harga batu bara sebagai bahan bakar subtitusi ikut terangkat. Penguatan harga batu bara dunia dan meningkatnya volume penjualan kuartal pertama 2008 karena tingginya permintaan dalam dan luar negeri, telah memberikan pengaruh positif terhadap kinerja perusahaan-perusahaan tambang batu bara, diantaranya perusahaan yang tergabung di JII seperti PT Tambang Batubara Bukit Asam Tbk (PTBA), PT Bumi Resource, Tbk. yang mencatatkan peningkatan laba. (www.okezone.com)

Berdasarkan uraian diatas yang menggambarkan adanya perbedaan hasil penelitian tentang variabel mempengaruhi perataan laba, hal ini mendorong penulis untuk melakukan pengujian kembali mengenai faktor-faktor yang mempunyai pengaruh terhadap perataanlaba pada perusahaan pertambangan yangterdaftar di Bursa Efek Indonesia. Adapun faktor-faktor yang akan diuji kembali dalam penelitian ini adalah ukuran perusahaan dan profitabilitas yang diproaksikan return on asset (ROA),

Beberapa fenomena relevan di atas yang terkait dengan permasalahan dapat di kemukakan sebagai kesulitan memperoleh modal dari investor dalam negeri cenderung membuat perusahaan melakukan praktik perataan laba, kemudian pengaruh profitabilitas terhadap perataan laba dari penelitian terdahulu ada yang menyatakan bahwa profitabilitas berpengaruh terhadap perataan laba, sedangkan peneliti lain menyatakan bahwa profitabilitas tidak berpengaruh pada perataan laba, jadi terjadi ketidak konsistenan pada penelitian terdahulu dan perlu untuk dilakukan pengujian kembali. Pengaruh ukuran perusahaan terhadap perataan laba, dari penelitian terdahulu menyatakan bahwa ukuran perusahan berpengaruh terhadap perataan laba, sedangkan peneliti lain menyatakan bahwa ukuran perusahaan tidakberpengaruh terhadap perataan laba. Jadi terjadi ketidak konsistenan pada penelitian terdahulu, dan perlu untuk dilakukan pengujian kembali. Namun demikian terdapat pembatasan lingkup kepada pembahasan ini atas variabel independen yang digunakan adalahUkuran 
Perusahaan yang diukur dengan Total Aktiva, Profitabilitas yang diukur dengan Return On Assets (ROA) dan Variabel dependen yang digunakan adalah Praktik Perataan Laba yang diukurdengan Indeks Perataan Laba (Indeks Eckel).

\section{Praktik Perataan Laba}

Zulhamri (2016) mendefinisikan praktik perataan laba (income smoothing) sebagai suatu upaya yang sengaja dilakukan manajemen untuk mencoba mengurangi variasi upnormal dalam laba perusahaan dengan tujuan untuk mencapai suatu tingkat yang normal bagi perusahaan. Kemudian, Sulistyanto (2008:91) menjustufikasi bahwa perataan laba (income smoothing) adalah salah satu bentuk manajemen laba. Perataan laba dapat di definisikan sebagai sebuah praktik yang digunakan manajemen baik secara artifisial baik melalui teknik-teknik dan metode akuntansi maupun rill (melalui transaksi ekonomi) yang bertujuan untuk mengurangi fluktuasi laba yang dilaporkan hingga mencapai tren dan level yang cenderung stabil dari suatu periode dengan periode sebelumnya".

Selanjutnya Alasan praktik perataan laba oleh manajemen menurut Putri (2016) adalah sebagai teknik untuk mengurangi laba dan menaikkan biaya padatahun berjalan sehingga pajak yang terhutang atas perusahaan menjadi kecil. Sebagai bentuk peningkatan citra perusahaan dimata investor, karena mendukung kestabilan penghasilan dan kebijakan deviden sesuai dengan keinginan investor ketika perusahaan mengalami kenaikan atas laba yang diperolehnya sebagai jembatan penghubung antara manajemen perusahaan dengankaryawannya.

\section{Kerangka Konseptual}

Berdasarkan landasan teori dan hasil penelitian sebelumnya serta permasalahan yang dikemukakan, maka sebagai acuan untuk merumuskan hipotesis, berikut disajikan kerangka pemikiran teroritis yang dituangkan dalam model penelitian seperti yang ditunjukan pada gambar berikut:

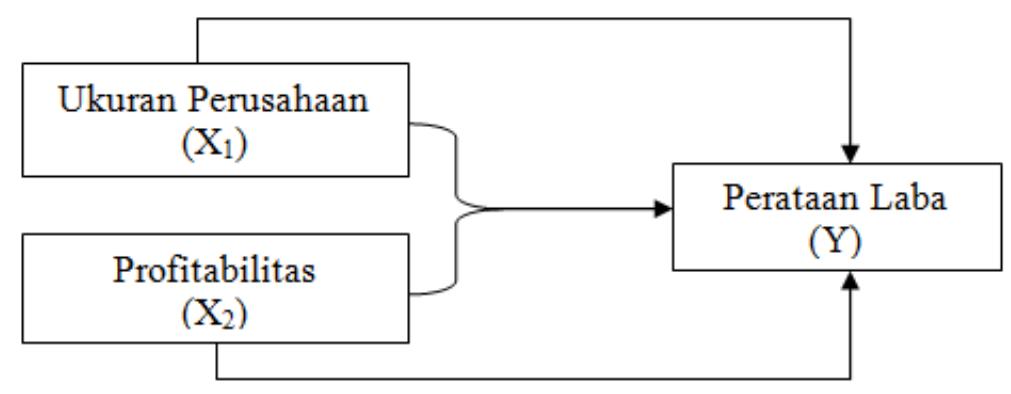

Gambar 1.1 kerangka konseptual

Berdasarkan literatur diatas maka penelitian ini memiliki beberapa hipotesis antara lain: H1: Ukuran perusahaan berpengaruh secara parsial terhadap praktik perataan laba (income smoothing).

H2:Profitabilitas berpengaruh secara parsial terhadap praktik perataan laba (income smoothing).

H3:Ukuran Perusahaan dan Profitabilitasberpengaruh secara simultan terhadap praktik Perataan Laba. 


\section{METODE PENELITIAN}

Dalam penelitian ini digunakan pendekatan kuantitatif yaitu penelitian yang menggunakan serta menyajikan data penelitian yang berupa angka-angka dan analisis dengan menggunakan analisis regresi linier berganda. Populasi dari penelitian ini adalah perusahaan pertambangan yang terdaftar di Bursa Efek Indonesia (BEI) pada periode tahun 2012-2016. Sampel penelitian dipilih dengan menggunakan metode purposive sampling yaitu pemilihans ampel saham perusahaan selama periode penelitian berdasarkan kriteria tertentu. terdapat 3 (tiga) kriteria sampling yang ditetapkandalam penelitian ini, yaitu; perusahaan pertambangan yang terdaftar danaktif di BEI sejak tahun 2012 dantetap terdaftar di BEI hingga tahun2016. Hal ini dimaksudkan untuk datayang berkesinambungan. perusahaan pertambangan yang memperoleh laba setiap tahunnya dari tahun 2012 sampai dengan tahun 2016, dan yang memiliki laporan keuangan disajikan dalam mata uang rupiah.

Tabel 1.1 Populasi dan Sampel Perusahaan Pertambangan yang Terdaftar di BEI dalam penelitian ini.

\begin{tabular}{|c|c|c|c|c|c|}
\hline \multirow{2}{*}{ Perusahaan } & \multirow{2}{*}{ Kode } & \multicolumn{3}{|c|}{ Kriteria } & \multirow{2}{*}{ Sampel } \\
\hline & & 1 & 2 & 3 & \\
\hline Adaro Energy Tbk & ADRO & $\sqrt{ }$ & $\sqrt{ }$ & $\sqrt{ }$ & 1 \\
\hline Atlas Resources Tbk & ARII & $\sqrt{ }$ & $\sqrt{ }$ & - & - \\
\hline Bara Jaya Internasional Tbk & ATPK & $\sqrt{ }$ & $\sqrt{ }$ & - & - \\
\hline Borneo Lumbung Energi \& Metal Tbk & BORN & $\sqrt{ }$ & - & $\sqrt{ }$ & - \\
\hline Borneo Olah Sarana Sukses Tbk & BOSS & $\sqrt{ }$ & - & $\sqrt{ }$ & - \\
\hline Baramulti Suksessarana Tbk & BSSR & $\sqrt{ }$ & $\sqrt{ }$ & $\sqrt{ }$ & 2 \\
\hline Bumi Resources Tbk & BUMI & $\sqrt{ }$ & $\sqrt{ }$ & - & - \\
\hline Bayan Resources Tbk & BYAN & $\sqrt{ }$ & $\sqrt{ }$ & - & - \\
\hline Darma Henwa Tbk & DEWA & $\sqrt{ }$ & - & $\sqrt{ }$ & - \\
\hline Delta Dunia Makmur Tbk & DOID & $\sqrt{ }$ & - & $\sqrt{ }$ & - \\
\hline Dian Swastatika Sentosa Tbk & DSSA & $\sqrt{ }$ & $\sqrt{ }$ & - & - \\
\hline Dwi Guna Laksana Tbk & DWGL & $\sqrt{ }$ & - & $\sqrt{ }$ & - \\
\hline Alfa Energi Investama Tbk & FIRE & $\sqrt{ }$ & - & $\sqrt{ }$ & - \\
\hline Golden Energy Mines Tbk & GEMS & $\sqrt{ }$ & $\sqrt{ }$ & - & - \\
\hline Garda Tujuh Buana Tbk & GTBO & $\sqrt{ }$ & - & $\sqrt{ }$ & - \\
\hline Harum Energy Tbk & HRUM & $\sqrt{ }$ & $\sqrt{ }$ & - & - \\
\hline Indo Tambangraya Megah Tbk & ITMG & $\sqrt{ }$ & $\sqrt{ }$ & $\sqrt{ }$ & 3 \\
\hline Resource Alam Indonesia Tbk & KKGI & $\sqrt{ }$ & $\sqrt{ }$ & - & - \\
\hline Mitrabara Adiperdana Tbk & MBAP & $\sqrt{ }$ & $\sqrt{ }$ & $\sqrt{ }$ & 4 \\
\hline Myoh Technology Tbk & MYOH & $\sqrt{ }$ & $\sqrt{ }$ & - & - \\
\hline Perdana Karya Perkasa & PKPK & $\sqrt{ }$ & - & $\sqrt{ }$ & - \\
\hline Bukit Asam Tbk & PTBA & $\sqrt{ }$ & $\sqrt{ }$ & $\sqrt{ }$ & 5 \\
\hline Petrosea Tbk & PTRO & $\sqrt{ }$ & $\sqrt{ }$ & - & - \\
\hline Golden Eagle Energy Tbk & SMMT & $\sqrt{ }$ & - & $\sqrt{ }$ & - \\
\hline Toba Bara Sejahtra Tbk & TOBA & $\sqrt{ }$ & $\sqrt{ }$ & $\sqrt{ }$ & 6 \\
\hline Kapuas Prima Coal Tbk & ZINC & $\sqrt{ }$ & $\sqrt{ }$ & - & - \\
\hline Apexindo Pratama Duta Tbk & APEX & $\sqrt{ }$ & $\sqrt{ }$ & - & - \\
\hline Ratu Prabu Energi Tbk & ARTI & $\sqrt{ }$ & $\sqrt{ }$ & $\sqrt{ }$ & 7 \\
\hline Benakat Integra Tbk & BIPI & $\sqrt{ }$ & - & $\sqrt{ }$ & - \\
\hline Elnusa Tbk & ELSA & $\sqrt{ }$ & $\sqrt{ }$ & $\sqrt{ }$ & 8 \\
\hline Energi Mega Persada Tbk & ENRG & $\sqrt{ }$ & - & $\sqrt{ }$ & - \\
\hline Surya Esa Perkasa Tbk & ESSA & $\sqrt{ }$ & $\sqrt{ }$ & $\sqrt{ }$ & 9 \\
\hline Medco Energi International Tbk & MEDC & $\sqrt{ }$ & $\sqrt{ }$ & - & - \\
\hline Radiant Utama Interinsco Tbk & RUIS & $\sqrt{ }$ & $\sqrt{ }$ & $\sqrt{ }$ & 10 \\
\hline Aneka Tambang (Persero) Tbk & ANTM & $\sqrt{ }$ & - & $\sqrt{ }$ & - \\
\hline Cita Mineral Investindo Tbk & CITA & $\sqrt{ }$ & - & $\sqrt{ }$ & - \\
\hline Cakra Mineral Tbk & CKRA & $\sqrt{ }$ & - & $\sqrt{ }$ & - \\
\hline Central Omega Resources Tbk & DKFT & $\sqrt{ }$ & - & $\sqrt{ }$ & - \\
\hline Vale Indonesia Tbk & INCO & $\sqrt{ }$ & $\sqrt{ }$ & $\sqrt{ }$ & 11 \\
\hline Merdeka Copper Gold Tbk & MDKA & $\sqrt{ }$ & $\sqrt{ }$ & - & - \\
\hline J Resources Asia Pasifik Tbk & PSAB & $\sqrt{ }$ & $\sqrt{ }$ & - & - \\
\hline SMR Utama Tbk & SMRU & $\sqrt{ }$ & - & $\sqrt{ }$ & - \\
\hline Timah (Persero) Tbk & TINS & $\sqrt{ }$ & $\sqrt{ }$ & $\sqrt{ }$ & 12 \\
\hline Citatah Tbk & CTTH & $\sqrt{ }$ & $\sqrt{ }$ & - & - \\
\hline Mitra Investindo Tbk & MITI & $\sqrt{ }$ & - & $\sqrt{ }$ & - \\
\hline
\end{tabular}




\section{Analisis Regresi Linier Berganda}

Persamaan regresi linier berganda merupakan persamaan regresi dengan menggunakan dua atau lebih variabel independen. Bentuk umum persamaan regresiberganda ini adalah:

$$
Y=a+b_{1} X_{1}+b_{2} X_{2}+e
$$

$$
\begin{array}{ll}
\text { dimana: } & \\
\mathrm{Y} & =\text { Praktik Perataan Laba Perusahaan } \\
\mathrm{a} & =\text { Konstanta } \\
\mathrm{X}_{1} & =\text { Ukuran Perusahaan } \\
\mathrm{X}_{2} & =\text { Profitabilitas } \\
\mathrm{e} & =\text { Error }
\end{array}
$$

Tabel 1.2 berikut merupakan mekanisme kriteria sample dalam penelitian ini

Tabel 1.2 Sampel Penelitian

\begin{tabular}{clc}
\hline No. & \multicolumn{1}{c}{ Kriteria } & Jumlah \\
\hline 1. & $\begin{array}{l}\text { Perusahaan pertambangan yang terus terdaftar dan aktif di BEI } \\
\text { antara periode 2012 - 2016 }\end{array}$ & 45 \\
2. & $\begin{array}{l}\text { Perusahaan pertambangan yang mengalami kerugian (laba negatif) } \\
\text { setiap tahunnya dari tahun 2012 - 2016 }\end{array}$ & $(17)$ \\
3. & Laporan Keuangan disajikan bukan dalam mata uang rupiah. & $(16)$ \\
\hline Jumlah sampel (akhir) & 12 \\
\hline
\end{tabular}

\section{HASIL DAN PEMBAHASAN}

Pada Tabel 1.3 di bawah menunjukkan bahwa sebanyak 60 pengamatan terdeteksi melakukan praktik perataan laba. Nilai minimum dari ukuran perusahaan sebesar 27,3084 yang merupakan ukuran In total asset PT. Mitrabara Adiperdana Tbk sedangkan nilai maksimum sebesar 32,1091 yang merupakan ukuran ln total asset PT. Adaro Energy Tbk. Nilai rata-rata (mean)dari ukuran perusahaan adalah sebesar 29,333487 dengan nilai standar deviasi sebesar 1,3435382.

Tabel 1.3 Deskriptif Statistik

\begin{tabular}{crrrrr} 
& N & Minimum & Maximum & \multicolumn{1}{c}{ Mean } & Std. Deviation \\
\hline Ukuran Perusahaan (X1) & 60 & 27.3084 & 32.1091 & 29.333487 & 1.3435382 \\
Profitabilitas (X2) & 60 & .0000 & 32.0000 & 6.894500 & 7.0836095 \\
Perataan Laba (Y) & 60 & -3.67 & 8.48 & .9800 & 2.90879 \\
Valid N (listwise) & 60 & & & & \\
\hline
\end{tabular}

Untuk profitabilitas nilai terkecil adalah 0 dan nilai maksimumnya adalah sebesar 32. Hal ini berarti perusahaan sampel mempunyai perbandingan antara laba bersih dan total aktiva paling sedikit adalah $0 \%$ dan perusahaan yang mempunyai perbandingan laba bersih terhadap total aktiva paling besar adalah $32 \%$. Nilai rata-rata (mean) dari profitabilitas adalah sebesar 6,894500 dengan nilai standar deviasi sebesar 7,0836095. 
Untuk Perataan Laba nilai minimum adalah sebesar -3.67 yang merupakan nilai Indeks Eckel dari PT. Bukit Asam,Tbk sedangkan nilai maksimum sebesar 8,48 merupakan nilai Indeks Eckel dari PT. Radiant Utama Interinsco Tbk. Nilai rata-rata dari perataan laba sebesar 0,98 dengan nilai standar deviasi sebesar 2,90879.

\section{Uji Normalitas}

Uji normalitas bertujuan untuk menguji apakah variabel dependen berdistribusi normal, yaitu menggunakan uji statistik Kolmogorov-Smirnov (K-S) dengan membuat hipotesis :

H0: Data residual berdistribusi normal.

H1: Data residual tidak berdistribusi normal.

Apabila nilai signifikannya $<0,05$, maka H0 ditolak, sedangkan apabila nilai signifikannya > 0,05, maka H0 diterima dapat dilihat dalam tabel 1.4 dibawah ini.

Tabel 1.4 Uji Kolmogrov-Smirnov

\begin{tabular}{lrr}
\hline & & \\
& & Unstandardized Residual \\
& Mean & 60 \\
Normal Parameters, & Std. Deviation & $0 \mathrm{E}-7$ \\
& Absolute & 2.68796279 \\
Most Extreme Differences & Positive & .125 \\
& Negative & .125 \\
Kolmogorov-Smirnov Z & -.083 \\
Asymp. Sig. (2-tailed) & .966 \\
& .308 \\
\hline a. Test distribution is Normal. & & \\
b. Calculated from data. &
\end{tabular}

Berdasarkan tabel 1.4 dapat dilihat bahwa nilai Kolmogorov-Smirnov sebesar 0,308 dan tidak signifikan pada 0,05 (karena $\mathrm{p}=0,308>0,05$ ) maka dapatdisimpulkan bahwa dari ketiga variabel ukuran perusahaan, profitabilitas dan perataan labamempunyai residual berdistribusi normal. Untuk lebih jelasnya, dapat di lihatjuga dengan menggunakan analisis normal probability plot dan grafik histogramberikut:

\section{Uji Multikolinearitas}

Uji multikolinearitas ini salah satu cara untuk mendeteksi ada tidaknyamasalah multikolinearitas adalah dengan melihat Variance Inflation Factor(VIF) dan nilai Tolerance. Bila nilai VIF kurang dari 5 dan nilai toleransi lebihdari 0,10 maka disimpulkan tidak terdapat multikolinearitas dalam modelregresi, begitu juga sebaliknya Bila nilai VIF lebih besar dari 5 dan nilaitoleransi kurang dari 0,10 maka disimpulkan terdapat multikolinearitas dalam model regresi. Hasil uji multikolinearitas disajikan dalam Tabel 1.5 berikut ini: 
Tabel 1.5 hasil Uji Multikolinearitas

\begin{tabular}{|c|c|c|c|c|c|c|c|}
\hline \multirow[t]{2}{*}{ Model } & \multicolumn{2}{|c|}{$\begin{array}{l}\text { Unstandardized } \\
\text { Coefficients }\end{array}$} & \multirow{2}{*}{$\begin{array}{c}\text { Standardized } \\
\text { Coefficients } \\
\text { Beta }\end{array}$} & \multirow[t]{2}{*}{$\mathrm{T}$} & \multirow[t]{2}{*}{ Sig. } & \multicolumn{2}{|c|}{$\begin{array}{l}\text { Collinearity } \\
\text { Statistics }\end{array}$} \\
\hline & B & Std. Error & & & & Tolerance & VIF \\
\hline (Constant) & 21.527 & 7.795 & & 2.762 & .008 & & \\
\hline $\begin{array}{c}\text { Ukuran Perusahaan } \\
\text { (X1) }\end{array}$ & -.679 & .265 & -.314 & -2.562 & .013 & 1.000 & 1.000 \\
\hline Profitabilitas (X2) & -.092 & .050 & -.223 & -1.822 & .074 & 1.000 & 1.000 \\
\hline
\end{tabular}

Dependent Variable: Perataan Laba (Y)

Pada Tabel 1.5 terlihat bahwa dari masing-masing variabel bebas terdapt nilai tolerance variabel ukuran perusahaan adalah 1,000 lebih besar dari 0,10sedangkan nilai Variance Inflation Factor (VIF) adalah 1.000 lebih kecil dari 10 maka dapat disimpulkan variabel ukuran perusahaan tidak terdapat multikolinearitas. Kedua, nilai tolerance variabel profitabilitas adalah 1,000 lebih besar dari 0,10 sedangkan nilai Variance Inflation Factor (VIF) adalah 1.000 lebihkecil dari 10 maka dapat disimpulkan variabel ukuran perusahaan tidakterdapat multikolinearitas.

\section{Uji Autokorelasi}

Pengujian autokorelasi ini dimaksudkan untuk mengetahui apakah terjadi korelasi di antara data pengamatan atau tidak. Ada tidaknya autokorelasi dalam penelitian ini dideteksi dengan menggunakan uji Durbin-Watson. Tahapan yang harus dilakukan untuk dapat menghasilkan harga koefisien Durbin-Watson yaitu sebagai berikut:

Tabel 1.6 Hasil Uji Autokorelasi

\begin{tabular}{|c|c|c|c|c|c|}
\hline Model & $\mathrm{R}$ & R Square & $\begin{array}{l}\text { Adjusted R } \\
\text { Square }\end{array}$ & $\begin{array}{l}\text { Std. Error of the } \\
\text { Estimate }\end{array}$ & Durbin-Watson \\
\hline 1 & $.382^{\mathrm{a}}$ & .146 & .116 & 2.73471 & .473 \\
\hline
\end{tabular}

Uji autokorelasi bertujuan untuk menguji apakah pada suatu model regresi linier ada korelasi antar kesalahan pengganggu pada periode satu dengan periode sebelumnya. Cara mendeteksinya melalui uji Durbin-Watson dengan ketentuan angka DW berada dibawah -2 , berarti ada autokorelasi positif, angka DW diantara -2 sampai +2 , berarti tidak ada autokorelasi, dan angka DW berada diatas +2 , berarti ada autokorelasi. Pada hasil pengujian diatas terlihat bahwa angka DW sebesar +0.473 atau $-2<0,473<+2$, karena angka DW berada diantara -2 dan +2 maka tidak terdapat autokorelasi. 


\section{Analisis Regresi Linier Berganda}

Regresi Linear berganda ditujukan untuk menentukan hubungan linear antar beberapa variabel bebas $(\mathrm{X})$ dengan variabel terikat $(\mathrm{Y})$. Model persamaan regresi ini yaitu:

Tabel 1.7 Analisis Regresi Linier Berganda

\begin{tabular}{|c|c|c|c|c|c|c|}
\hline \multicolumn{2}{|r|}{ Model } & \multicolumn{2}{|c|}{ Unstandardized Coefficients } & \multirow{2}{*}{$\begin{array}{c}\text { Standardized } \\
\text { Coefficients } \\
\text { Beta }\end{array}$} & \multirow[t]{2}{*}{$\mathrm{t}$} & \multirow[t]{2}{*}{ Sig. } \\
\hline & & B & Std. Error & & & \\
\hline \multirow{3}{*}{1} & (Constant) & 21.527 & 7.795 & & 2.762 & .008 \\
\hline & Ukuran Perusahaan (X1) & -.679 & .265 & -.314 & -2.562 & .013 \\
\hline & Profitabilitas (X2) & -.092 & .050 & -.223 & -1.822 & .074 \\
\hline
\end{tabular}

Dependent Variable: Perataan Laba (Y)

Berdasarkan tabel di atas dapat di bentuk persamaan:

$$
Y=21,527-0.679 X_{1}-0.092 X_{2}+e
$$

Maka dapat dijelaskan konstanta sebesar 22,946 artinya jika variable ukuranperusahaan dan profitabilitas adalah 22 (dianggap kostan), maka praktik perataan laba yangterjadi adalah sebesar 22,946. Koefisien regresi variabel ukuran perusahaan $\left(\mathrm{X}_{1}\right)$ sebesar -0,679 artinya jikavariabel bebas lain nilainya tetap dan ukuran perusahaan mengalamikenaikan sebesar $1 \%$, maka praktik perataan laba akan berkurang sebesar $-0,679$. Koefisien bernilai negatif artinya terjadi hubungan negatif antara ukuran perusahaan terhadap praktik perataan laba. Koefisien regresi variabel profitabilitas $\left(\mathrm{X}_{2}\right)$ sebesar -0.092 artinyajikavariabel bebas lain nilainya tetap dan profitabilitas mengalamikenaikan sebesar 1\%, maka praktik perataan laba akan berkurang sebesar $-0,092$. Koefisien bernilai negatif artinya terjadi hubungan negatif antara profitabilitas terhadap praktik perataan laba.

\section{Uji Determinasi}

Tabel 1.8 Hasil Uji Determinasi

\begin{tabular}{ccccr}
\hline Model & R & R Square & Adjusted R Square & $\begin{array}{c}\text { Std. Error of the } \\
\text { Estimate }\end{array}$ \\
\hline 1 & $.382^{\mathrm{a}}$ & .146 & .116 & 2.73471 \\
\hline a. Predictors: (Constant), Profitabilitas (X2), Ukuran Perusahaan (X1) &
\end{tabular}

Berdasarkan tabel 1.8 diatas memperlihatkan bahwa nilai $\mathrm{R}=0.382 \mathrm{a}$ berarti hubungan antara variabel bebas ukuran perusahaan dan profitabilitas berpengaruhterhadap praktik perataan laba adalahsebesar 38,2\% yang artinya hubungan sedikit erat. Kemudian, Adjusted $R$ Square sebesar 0.116 yang berarti 11,6\% faktor-faktor yang mempengaruhi praktik perataan labadapatdijelaskan secara bebas oleh ukuran perusahaan dan profitabilitas sedangkan selebihnya sebesar $88,4 \%$ dijelaskan oleh faktor lain yang tidak diteliti di dalam penelitian 


\section{Uji t (Uji Parsial)}

Pengujian ini dilakukan untuk mengetahui apakah hipotesis yang diajukan diterima atau ditolak dengan menggunakan statistik t (Uji Secara Parsial). Hasil uji statistik t (uji secara parsial) ini yaitu:

Tabel 1.9 Hasil Uji Parsial ( $\mathrm{t}$ )

\begin{tabular}{lcrrrrr}
\hline & Model & Unstandardized Coefficients & \multicolumn{2}{c}{$\begin{array}{c}\text { Standardized } \\
\text { Coefficients } \\
\text { Beta }\end{array}$} & \multicolumn{1}{c}{ T } & Sig. \\
& B & Std. Error & 7.795 & & 2.762 & .008 \\
\hline \multirow{4}{*}{$1 \quad$ (Constant) } & 21.527 & -.795 & -.314 & -2.562 & .013 \\
& Ukuran Perusahaan (X1) & -.679 & .265 & -.223 & -1.822 & .074 \\
\hline
\end{tabular}

Dependent Variable: Perataan Laba (Y)

Berdasarkan Tabel 1.9 hasil olahan dari model SPSS, maka dapat disimpulkan hasil signifikansi atau perusahaan adalah -2,562 dengan tingkat signifikansi 0.013 maka variabel ukuran perusahaan tidak berpengaruh terhadap praktik perataan laba dengan nilai thitung $(-2,562)<t_{\text {tabel }}(2.00247)$ dan nilai signifikan $(0,013$ pengaruh variabel-variabel independen terhadap variabel dependen Nilai thitung untuk ukuran) $>0.05$. Ho diterima dan Ha ditolak jika t hitung < t tabel. Artinya variable bebas tidak berpengaruh secara signifikan terhadap variabel terikat. Nilai thitung untuk profitabilitas adalah -1.822 dengan tingkat signifikansi 0.074 maka variabel ukuran perusahaan tidak berpengaruh terhadappraktik perataan laba dengan nilai thitung $(-1.822)<t_{\text {tabel }}(2.00247)$ dan nilai signifikan $(0,074)>0.05$. Ho diterima dan Ha ditolak jika $t$ hitung $<t$ tabel. Artinya variabelbebas tidak berpengaruh secara signifikan terhadap variabel terikat. Nilai tabel (2.00247). Dalam hal ini $\mathrm{n}$ adalah 12 unit perusahaan dikalikan 4 tahun penelitian $=48$, sedangkan $\mathrm{k} 4$ yang terdiri dari 3 variabel terikat dan 1 variabel bebas. Pada analisis regresi digunakan profitabilitas 2 sisi, misalnya nilaitabel distribusi t dicari pada a $5 \%: 2$ $=2,5 \%$. (tabel $t$ ada pada lampiran).

\section{Uji F (Uji Simultan)}

Pengujian ini dilakukan untuk mengetahui apakah hipotesis yang diajukanditerima atau ditolak digunakan statistik F (Uji Secara Simultan). Hasil uji statistik F (Uji Secara Simultan) ini yaitu:

Tabel 1.10 Hasil Uji Simultan (F)

\begin{tabular}{rrrrrrr}
\hline & Model & Sum of Squares & Df & Mean Square & F & \multicolumn{1}{c}{ Sig. } \\
\hline \multirow{4}{*}{1} & Regression & 72.920 & 2 & 36.460 & 4.875 & $.011^{\mathrm{b}}$ \\
& Residual & 426.283 & 57 & 7.479 & & \\
& Total & 499.203 & 59 & & & \\
\hline
\end{tabular}

a. Dependent Variable: Perataan Laba (Y)

b. Predictors: (Constant), Profitabilitas (X2), Ukuran Perusahaan (X1)

Pada Tabel 1.10 dapat dilihat bahwa diperoleh nilai $\mathrm{F}$ hitung adalah 4,875 dengan tingkat signifikansi 0.011a. Dengan penggunaan tingkat signifikansi $(\alpha) 5 \%$. Berdasarkan Tabel diperoleh 0,011<0,05 ini menunjukan bahwa terdapatpengaruh signifikan secara simultan dari variabel independen terhadap variable dependen. Degree of freedom (Df) atau derajatkebebasan (Dk). Pada tabel $\mathrm{f}$, degree of freedom dibagi menjadi 2, yaitu, mengetahui jumlah variabel yang diteliti $(\mathrm{k})=3$, dan mengetahui jumlah data/observasi/responden $(\mathrm{n})=60$ 
1. Degree of freedom sebagai pembilang atau $\mathrm{df}(\mathrm{n} 1)$

2. Degree of freedom sebagai pembilang atau $\mathrm{df}(\mathrm{n} 2)$

$\operatorname{Df}(\mathrm{n} 1)=\mathrm{k}-1=3-1=2$

$\operatorname{Df}(\mathrm{n} 2)=\mathrm{n}-\mathrm{k}=60-3=57$

Maka disimpulkan nilai untuk df (n1) adalah 2 dan df (n2) 57, kemudian lihat nilai f tabel adalah 3,16 dengan nilai signifikansi 5\% $=0.05 \mathrm{~F}$ hitung 4,875> F tabel3,16 maka: Ha diterima dan Ho ditolak jika f hitung $>\mathrm{f}$ tabel. Artinya variabel bebas secara bersamasama berpengaruh secara signifikan terhadap variable terikat.

Pengaruh Ukuran Perusahaan Secara Parsial Terhadap Praktik Perataan Laba.

Hasil penelitian menunjukkan bahwa secara parsial ukuran perusahaan tidak berpengaruh signifikan terhadap praktik perataan laba hal ini dapat dilihat bahwa ukuran perusahaan nilaisignifikansi 0.013 yang berarti nilai ini lebih kecil dari 0,05 , sedangkan nilaithitung $(-2.562)<t_{\text {tabel }}(2.01537)$. Variabel ukuran perusahaan mempunyai arah koefisien negatif dan tidak mempunyai signifikansi positif terhadap tindakan perataan laba. Hasil penelitian ini sejalan denganpenelitian Aprilina Mafiana (2015) yang menyatakan bahwa ukuran perusahaan tidak mempunyai pengaruh yang signifikan terhadap perataan laba. Hal ini dapat dilihat dari uji hipotesis dimana nilai signifikasi ukuran perusahaan adalah 0,521 $>0,05$ dan nilai $\beta 2=0,102$. Hasil penelitian terhadap variabel profitabilitas menunjukkan bahwa nilai koefisien variabel ROAsebesar $-1,822$ $<2.01537$ dengan tingkat signifikasi 0,074 >0,05. Hal ini berarti bahwa $\mathrm{H}_{\mathrm{o}}$ diterima dan Ha ditolak .Dengan demikian dapat dikatakan bahwa variabel return on asset secara parsial tidak berpengaruh signifikan terhadap perataan laba pada perusahaan pertambangan yang terdaftar di Bursa Efek Indonesia periode 2012-2016. Hasil penelitian ini tidak sejalan dengan penelitian Aprilina Mafiana (2015) yang menyatakan bahwa profitabilitas mempunyai pengaruh positif terhadap perataan laba. Hal ini dapat dilihat dari uji hipotesis dimana nilai signifikasi profitabilitas adalah 0,757 < 0,05 dan dengan nilai koefisien regresi -0,016.

\section{Pengaruh Ukuran Perusahaan dan Profitabilitas secara simultan terhadap Praktik Perataan Laba}

Hasil penelitian menunjukkan bahwa secara simultan atau bersama-sama ukuran perusahaan dan profitabilitas berpengaruh signifikan terhadap praktik perataan laba hal

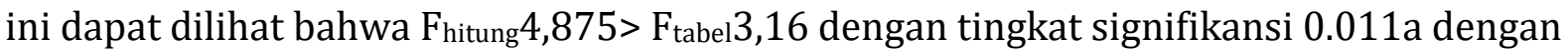
penggunaan tingkat signifikansi $(\alpha) 5 \%$. Maka Ha diterima dan Ho ditolak jika f hitung $>\mathrm{f}$ tabel. Artinya variabel bebas secara bersama-sama berpengaruh secara signifikan terhadap variabel terikat. Hasil penelitian ini tidak sejalan denganpenelitian Aprilina Mafiana (2015) yang menyatakan bahwa jenis industri tidak mempunyai pengaruh yang signifikan terhadap perataan laba.Hal ini dapat dilihat dari uji hipotesis dimana nilai signifikasi jenis industri adalah 0,235 $>0,05$ dan nilai $\beta 3=-0,738$.

\section{SIMPULAN}

Berdasarkan hasil analisis data serta pembahasan yang telah dilakukan, maka penelitian ini menghasilkan kesimpulan bahwa ukuran perusahaan dan profitabilitas tidak berpengaruh signifikan secara parsial terhadap praktik perataan laba (Studi kasus perusahaan pertambangan yang terdaftar di Bursa Efek Indonesia), profitabilitas tidak berpengaruh signifikan secara parsial terhadap praktik perataan laba (Studi kasus perusahaan pertambangan yang terdaftar di Bursa Efek Indonesia), untuk ukuran perusahaan dan profitabilitas berpengaruh signifikan secara simultan terhadap praktik 
perataan laba (Studi kasus perusahaan pertambangan yang terdaftar di Bursa Efek Indonesia). Penelitian yang akan datang sebaiknya memperbanyak sampel penelitian agar hasil penelitian tentang perataan laba menjadi lebih berkembang serta menggunakan metode yang berbeda agar didapatkan hasil penelitian baru yang dapat digunakan sebagai referensi bagipenelitian selanjutnya. Untuk penelitian yang akan datang diharapkan juga dapat menguji beberapa variabel lain yang diduga memiliki pengaruh terhadap perataan laba, seperti kebijakan akuntansi, peraturan pemerintah, dan kompensasi bagi manajemen, harga saham, struktur kepemilikan, dan sektor industri. Melakukan pengamatan objek yang lebih luas tidak hanya satu sektor pertambangan saja sehingga dapat dijadikan acuan untuk suatu permasalahan. Untuk penelitian yang akan datang diharapkan juga dapat menguji beberapa variabel lain yang diduga memiliki pengaruh terhadap perataan laba, seperti kebijakan akuntansi, peraturan pemerintah, dan kompensasi bagi manajemen, harga saham, struktur kepemilikan, dan sektor industri.

\section{DAFTAR PUSTAKA}

Agus Sartono. 2012. Manajemen Keuangan Teori dan Aplikasi. Edisi4. BPFE. Yogyakarta.

Bambang Riyanto. 2008. Dasar-Dasar Pembelanjaan Perusahaan. BPFE. Yogyakarta.

Bastian, H., Wiagustini, L. P., \& Artini, L. G. S. (2018). Pengaruh EVA dan kinerja keuangan terhadap return saham perusahaan tambang batubara di indonesia. Buletin Studi Ekonomi, 77-91.

Bestivano, Wildham. 2013. Pengaruh Ukuran Perusahaan, Umur Perusahaan, Pofitabilitas dan Financial Leverage terhadap Perataan Laba pada Perusahaan yang Terdaftar di BEI. Padang: Skripsi Universitas Negeri Padang.

Dewi, Diastiti Okkarisma. 2010. "Pengaruh Jenis Usaha, Ukuran PerusahaanDan Financial Leverage Terhadap Tindakan Perataan Laba PadaPerusahaan Manufaktur Yang Terdaftar Di BEI". Skripsi. Semarang: Universitas Diponegoro.

Fiatmoko, Arizal Latif dan Indah Anisyukurillah. 2015. Faktor-Faktor yang Berpengaruh terhadap Audit Delay pada Perusahaan Perbankkan. ISSN 2252 -6765 Jurnal UNNES.

Hartono, Jogiyanto. 2008. Teori Portofolio dan Analisis Investasi Edisi Kelima. BPFE. Yogyakarta.

Ikatan Akuntan Indonesia. 2012. Standar Akuntansi Keuangan. Jakarta: IAI.

Kasmir. 2012. Analisis Laporan Keuangan. Jakarta: RajaGrafindo Persada.

Lestari , Yuli Ratna Duwi. 2017. "Pengaruh Profitabilitas, Financial LeverageDan Ukuran Perusahaan Terhadap Perataan Laba Pada PerusahaanManufaktur Sub Sektor Makanan Dan Minuman Yang Terdaftar Di BEIPeriode 2011-2014". Jurnal. Kediri: Universitas Nusantara PGRI.

Lukman Syamsudin. 2007. Manajemen keuangan perusahaan.Jakarta :Raja Grafindo Persada.

Permatasari, Susanti. 2017. "Pengaruh Ukuran Perusahaan Dan ProfitabilitasTerhadap Nilai Perusahaan Dengan Manajemen Laba Sebagai Variabel Intervening”. Jurnal Ilmu dan Riset Akuntansi. Volume 6 Nomor 9, September 2017.

Putri, Dian Rhamanda. 2016. "Pengaruh Profitabilitas, ResikoKeuangan, Nilai Perusahaan Dan Struktur Kepemilikan Manajerial Terhadap Perataan Laba (Income Smoothing) Pada Perusahaan Manufaktur Yang Terdaftar Di BEI Periode 2012-2014”.Skripsi. Lampung: Universitas Lampung.

Sugiyono. 2010. Metode Penelitian Kuantitatif R\&D. Bandung: Alfabeta.

Sujarweni, V. Wiratna. 2018. Metode Penelitian Bisnis dan Ekonomi Pendekatan Kuantitatif. Yogyakarta: Pustaka Baru Press.

Sulistyanto, Sri. 2008. Manajemen Laba Teori dan Model Empiris. Grasindo: Jakarta.

Zulhamri, Lya. 2016."Pengaruh Ukuran Perusahaan, Profitabilitas Dan Financial Leverage Terhadap Praktik Perataan Laba (IncomeSmoothing) Pada Perusahaan Pertambangan Yang Terdaftar di BEI". Skripsi. Bandung: Universitas Pasundan 